\title{
Osthole suppresses the proliferation and accelerates the apoptosis of human glioma cells via the upregulation of microRNA-16 and downregulation of MMP-9
}

\author{
KAI LIN ${ }^{1}$, ZHIYU GAO ${ }^{1}$, BIN SHANG ${ }^{2}$, SHAOHUA SUI ${ }^{1}$ and QIANG FU ${ }^{1}$ \\ ${ }^{1}$ Department of Neurosurgery, Liaocheng People's Hospital and Liaocheng Clinical School of Taishan Medical University, \\ Liaocheng, Shandong 252000; ${ }^{2}$ Department of Neurosurgery, Central Hospital of Nanchong, \\ North Sichuan Medical College, Nanchong, Sichuan 637000, P.R. China
}

Received August 31, 2014; Accepted May 13, 2015

DOI: $10.3892 / \mathrm{mmr} .2015 .3929$

\begin{abstract}
Osthole (7-methoxy-8-isoamyl alkenyl coumarin) has been reported to exhibit marked anticancer effects on several types of cancer. The expression levels of matrix metalloproteinase-9 (MMP-9) are closely associated with the pathogenesis of glioma. Furthermore, it is reported that the upregulation of microRNA-16 (miR-16) by the MMP-9 signaling pathway can restrain the proliferation of cancer cells. To examine whether osthole increases the anticancer effect on human glioma cells in the present study, the common glioma cell line, U87, was treated with osthole at concentrations of $0,50,100$ and $200 \mu \mathrm{M}$. The effects of osthole on cell viability were determined using a 3-(4,5-dimethylthiazol-2-thiazolyl)-2,5-diphenyl-tetrazolium bromide assay. The rate of cellular apoptosis was analyzed by measuring the activity of caspase-3 and using flow cytometry. The expression of MMP-9 was determined using gelatin zymography assays and the expression of miR-16 was determined using reverse transcription-quantitative polymerase chain reaction. The results demonstrated that osthole significantly suppressed the proliferation and accelerated the apoptosis of the U87 cells. Furthermore, increased expression levels of miR-16 and reduced protein expression levels of MMP-9 were found in the U87 cells. In addition, miR-16 was found to regulate the expression of MMP-9 in the U87 cells through transfection of miR-16 precursor and anti-miR-16 into the U87 cells. In conclusion, these observations indicated that osthole suppressed the proliferation and accelerated the apoptosis of human glioma cells through upregulation of the expression of miR-16 and downregulation of the expression of MMP-9.
\end{abstract}

Correspondence to: Dr Qiang Fu, Department of Neurosurgery, Liaocheng People's Hospital and Liaocheng Clinical School of Taishan Medical University, 3 Huashan Road, Liaocheng, Shandong 252000, P.R. China

E-mail: qiangfumr@163.com

Key words: osthole, glioma cells, microRNA-16, matrix metalloproteinase-9, proliferation, apoptosis

\section{Introduction}

It is well known that glioma accounts for $44.6 \%$ of tumors of the central nervous system and has the characteristics of a high recurrence rate and high mortality rate (1). Although certain surgical comprehensive treatments can significantly improve the survival rates of patients with glioma, the prognosis remains poor due to the occurrence of chemotherapy drug resistance in glioma therapy (2).

Matrix metalloproteinases (MMPs) are reported to interact with the cellular adhesive molecular degradation of the extracellular matrix, promoting the growth of tumor cells into the surrounding brain tissue (3). Cell proliferation may be affected by regulating MMP-9 activity, and MMP-9 activity is controlled by several factors, including the quantity and activation of enzymes (4). MMP-9 is correlated with glioma and it has been demonstrated that the expression levels of MMP-9 directly reflect the prognosis of patients with glioma and is the preferred predictor of invasive glioma cell growth $(5,6)$.

MicroRNAs (miRNAs) are a series of non-coding, small molecule RNAs, which regulates gene expression via sequence complementation. These small RNAs consist of between 19 and 25 nucleotides (7). Following transcription, they exert inhibitory effects on gene expression and are involved in several physiological processes, including cell differentiation, apoptosis and metabolism (8). Previous studies have demonstrated that miR-16 is important in tumors of various origins (9-11). In glioma growth and invasiveness, the importance of miR-16 as a tumor suppressor gene and a novel mechanism of miR-16 regulation through inhibition the nuclear factor (NF)- $\mathrm{B} 1 / \mathrm{MMP}-9$ signaling pathway has been reported (11).

Osthole is a natural coumarin isolated from umbelliferae plant monomers (ripe fruit). A previous modern pharmacological investigation demonstrated that osthole has anti-inflammatory, antioxidant and other pharmacological properties $(12,13)$. In addition, it was also revealed that osthole markedly decreases the activity and protein content of MMP-9, suggesting that this protective effect at the molecular level may be due to downregulation of the MMP-9 pathway (14). The aim of the present study was to investigate the anticancer potential of osthole against glioma cells and examine whether 
this mechanism is dependent on the upregulation of miR-16 and downregulation of MMP-9 expression.

\section{Materials and methods}

Reagents and chemicals. The chemical structure of osthole (Sigma-Aldrich, St. Louis, MO, USA; purity, $\geq 95 \%$ ) is shown in Fig. 1. Osthole was dissolved in physiological saline (50-200 $\mu \mathrm{M})$. Roswell Park Memorial Institute-1640 (RPMI-1640) medium, fetal calf serum (FCS) and Lipofectamine 2000 were purchased from Invitrogen Life Technologies (Carlsbad CA, USA). 3-(4,5-dimethylthiazol-2-thiazolyl)-2,5-diphenyl-tetrazolium bromide (MTT) was purchased from Beyotime Institute of Biotechnology, (Haimen, China). The Annexin V-fluorescein isothiocyanate (FITC)/propidium iodide (PI) Double Staining kit was purchased from BestBio (Shanghai, China).

Cancer cell lines. The U87 glioma cell line was purchased from the Animal Experiments of Clinical School of Taishan Medical University (Taian, China). The U87 cells were cultured in RPMI-1640 medium, supplemented with $10 \%$ FCS, $100 \mathrm{U} / \mathrm{ml}$ penicillin and $100 \mathrm{mg} / \mathrm{ml}$ streptomycin, at $37^{\circ} \mathrm{C}$ and $5 \% \mathrm{CO}_{2}$.

MTT viability assay. The effect of osthole on the proliferation of U87 cells was measured using an MTT assay. The U87 cells $\left(5.0 \times 10^{3}\right.$ cells/well) were seeded into 96 -well culture plates at $95 \%$ confluence and incubated at $37^{\circ} \mathrm{C}$ and $5 \% \mathrm{CO}_{2}$ in a humidified incubator for $24 \mathrm{~h}$. Following incubation, the cells were treated with different concentrations of osthole $(0,50$, 100 or $200 \mu \mathrm{M})$ for $0,24,48$ or $72 \mathrm{~h}$. MTT $(\sim 10 \mu \mathrm{l}$ of $10 \mathrm{mg} / \mathrm{ml})$ was added into each well and incubated at $37^{\circ} \mathrm{C}$ and $5 \% \mathrm{CO}_{2}$ for $4 \mathrm{~h}$. Subsequently, $150 \mu \mathrm{l}$ dimethyl sulfoxide was added to each well and incubated for $20 \mathrm{~min}$ at room temperature with agitation. The absorbance of the plates was detected using an CM2600d spectrometer (Bio-Tek Instruments, Inc., Winooski, VT, USA) at $570 \mathrm{~nm}$.

Measurement of caspase-3 activity. The activity of caspase-3 in the cells was measured using a Colorimetric Caspase-3 Assay kit (Beyotime Institute of Biotechnology). Following treatment with $100 \mu \mathrm{M}$ osthole for $48 \mathrm{~h}$, the U87 cells $\left(1.0-2.0 \times 10^{6}\right.$ cells/well) were centrifuged at $12,300 \times \mathrm{g}$ for $20 \mathrm{~min}$ at $4^{\circ} \mathrm{C}$. The supernatant was collected and the protein concentration was quantified using a bicinchoninic acid (BCA) protein assay kit (Sangon Biotech, Shanghai, China). The protein extract $(\sim 50 \mu \mathrm{g})$ was incubated and added to a reaction buffer containing $90 \mu \mathrm{l} 1 \mathrm{X}$ assay buffer and $10 \mu \mathrm{l}$ Ac-DEVD-pNA caspase-3 substrate at $37^{\circ} \mathrm{C}$ for $6 \mathrm{~h}$. The protein extract $(\sim 50 \mu \mathrm{g})$ was incubated at $37^{\circ} \mathrm{C}$ and added to a reaction buffer containing $90 \mu \mathrm{l} 1 \mathrm{X}$ assay buffer (Beyotime Institute of Biotechnology) and $10 \mu \mathrm{l}$ Ac-DEVD-pNA caspase-3 substrate (Beyotime Institute of Biotechnology) at $37^{\circ} \mathrm{C}$ for $6 \mathrm{~h}$. The change was calculated using a CM2600d spectrometer at a wavelength of $405 \mathrm{~nm}$ (Bio-Tek Instruments, Inc.).

Annexin V/PI flow cytometric analysis. The apoptotic rates of the U87 cells were determined using flow cytometric analysis (BD Biosciences, Franklin Lakes, NJ, USA) using an Annexin V-FITC/PI apoptosis kit. Following treat- ment with $100 \mu \mathrm{M}$ osthole for $48 \mathrm{~h}$, the U87 cells were collected and washed twice with phosphate-buffered saline. Annexin V-FITC $(10 \mu \mathrm{l})$ was added to the U87 cells, following which the cells were stained with binding buffer (BestBio) for $30 \mathrm{~min}$ in the dark, according to the manufacturer's instructions. PI $(10 \mu \mathrm{l})$ was added to the glioma cell samples, which were then incubated for $30 \mathrm{~min}$ at room temperature in the dark. Immediately following incubation, the samples were analyzed using flow cytometry.

MMP-9 measurement. To determine whether $100 \mu \mathrm{M}$ osthole induced the expression of MMP-9 in the U87 cells, gelatin zymography assays were used. Following treatment with osthole for $48 \mathrm{~h}$ at $37^{\circ} \mathrm{C}$, the U87 cells were harvested and the concentration of protein was determined using a BCA protein assay kit (Sangon Biotech). Equal quantities of protein were extracted and were subsequently electrophoresed on 10\% SDS-PAGE gels (Beyotime Institute of Biotechnology), containing 1\% gelatin. Following electrophoresis, the gel was rinsed in 2\% Triton X-100 (Nanjing Senbeijia Biotech Company, Nanjing, China) for $1 \mathrm{~h}$ and subsequently washed in water. The gels were incubated in radioimmunoprecipitation assay buffer ( $\mathrm{pH}$ 8.0; Sigma-Aldrich) at $37^{\circ} \mathrm{C}$ for $12 \mathrm{~h}$ and the gel was stained with $0.2 \%$ Coomassie Blue R-250 (Beyotime Institute of Biotechnology) for $1 \mathrm{~h}$. The protein expression levels of MMP-9 were quantified using a MiniBis system (DNR Bio-Imaging Systems Ltd., Jerusalem, Israel) and prestained SDS-PAGE standards (Houbio Tech Co., Ltd., Fan Ling, Hong Kong).

Reverse transcription-quantitative polymerase chain reaction $(R T-q P C R)$ of the expression of $m i R-16$. The present study investigated whether $100 \mu \mathrm{M}$ osthole induced the expression of miR-16 in the U87 cells using RT-qPCR. Following treatment with osthole for $48 \mathrm{~h}$ at $37^{\circ} \mathrm{C}$, the total RNA was extracted from the cells using TRIzol reagent (Invitrogen Life Technologies), according to manufacturer's instructions. Approximately $1 \mu \mathrm{g}$ total RNA from U87 cells-treated was used to perform the first-strand cDNA synthesis. Subsequently, $2 \mathrm{ml}$ RNA was transcribed to cDNA using random hexamers (Promega, Madison, WI, USA) according to the manufacturer's instructions. The cycling conditions were as follows: $10 \mathrm{~min}$ at $95^{\circ} \mathrm{C}$, 40 cycles of $45 \mathrm{sec}$ at $95^{\circ} \mathrm{C}, 45 \mathrm{sec}$ at $58^{\circ} \mathrm{C}$ and $45 \mathrm{sec}$ at $72^{\circ} \mathrm{C}$. The quantification of the miR-16 level was conducted by realtime PCR using TransStart ${ }^{\mathrm{TM}}$ SYBR Green qPCR Supermix (TransGen Biotech, Beijing, China) and U6 small nuclear RNA was regarded as an endogenous reference gene. The U6 primer sequence was as follows: Forward 5'-CTCGCTTCGGCA GCACA-3' and reverse 5'-AACGCTTCACGAATTTGCGT-3'. The miR-16 primer sequence was as follows: Forward 5'-TTC CATGCTGTTTTGGTCCC-3' and reverse 5'-TGGGTGGAG GTTTGTTCGGA-3'. Primers were provided by Sangon Biotech Co., Ltd. (Shanghai, China). Relative quantification was carried out using the $2^{-\Delta \Delta \mathrm{Ct}}$ cycle threshold method.

miR-16 and anti-miR-16 transfection. The miR-16 precursor and the anti-miR-16 were obtained from KeyGen Biotech Co., Ltd. (Nanjing, China). The U87 cells $\left(5 \times 10^{5}\right.$ cells/well) were cultured in six-well plates and transfected with either miR-16 precursor or anti-miR-16 using Lipofectamine 2000 for $6 \mathrm{~h}$ at $37^{\circ} \mathrm{C}$. The transfection media was replaced with RPMI-1640 


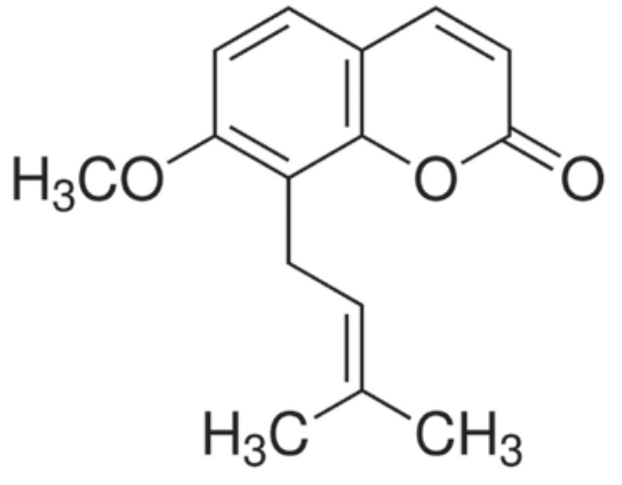

Figure 1. Chemical structure of osthole.

A

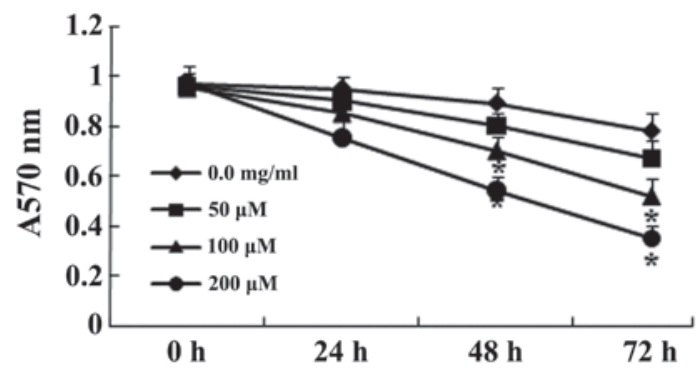

B

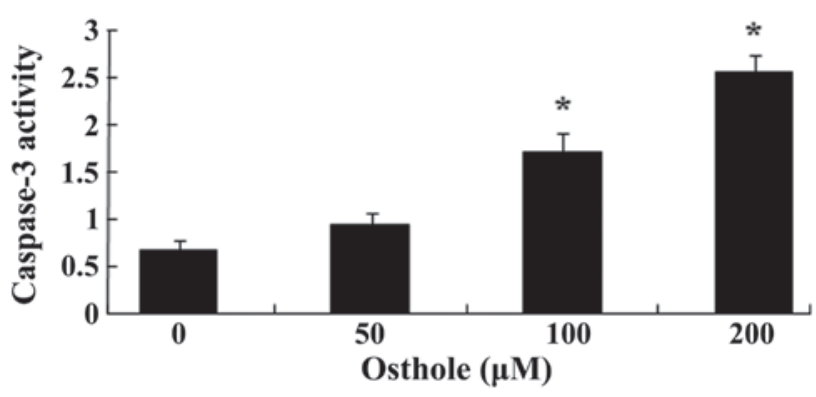

Figure 2. Osthole inhibits U87 cell growth and increases capsase-3 activity. A 3-(4,5-dimethylthiazol-2-thiazolyl)-2,5-diphenyl-tetrazolium bromide assay was used to measure cell proliferation and the activity of caspase-3 was determined. Treatment with osthole (A) dose-dependently inhibited the growth of U87 cells and (B) significantly increased the activity of caspase-3 Data are presented as the mean \pm standard deviation ( $\mathrm{P}<0.05$, compared with the $0 \mu \mathrm{M}$ osthole treatment group).

containing $10 \%$ FCS without antibiotic in a humidified atmosphere at $37^{\circ} \mathrm{C}$ with $5 \% \mathrm{CO}_{2}$ for $18 \mathrm{~h}$.

Statistical analysis. All data are presented as the mean \pm standard deviation. The data were analyzed using Student's t-test. Statistical analysis was performed using SPSS 17.0 (SPSS, Inc., Chicago, IL, USA). $\mathrm{P}<0.05$ was considered to indicate a statistically significant difference.

\section{Results}

Osthole suppresses proliferation and increases caspase-3 activity in the U87 cells. To determine whether there is an association between osthole and U87 cells, the viability of U87 cells following treatment with different concentrations of osthole $(0,50,100$ or $200 \mu \mathrm{M})$ was determined using an
MTT assay. As shown in Fig. 2A, the analysis revealed that treatment with $50 \mu \mathrm{M}$ osthole for $72 \mathrm{~h}$ significantly reduced U87 cell viability, and treatment with 100 and $200 \mu \mathrm{M}$ for $48 \mathrm{~h}$ or $72 \mathrm{~h}$ significantly reduced U87 cell viability. In addition, the decrease in U87 cell viability was found to occur in a time- and concentration-dependent manner in the osthole-treated cells. The activity of caspase- 3 in the U87 cells was analyzed following treatment with osthole $(0,50,100$ or $200 \mu \mathrm{M}$ ) using a caspase-3 assay. Following treatment with 100 or $200 \mu \mathrm{M}$ osthole for $48 \mathrm{~h}$, the activity of caspase-3 was significantly increased in the U87 cells $(\mathrm{P}<0.05)$, and this increase in the activity of caspase- 3 occurred in a concentration-dependent manner in the osthole-treated cells (Fig. 2B).

Flow cytometric analysis for the detection of cellular apoptosis. The U87 cells were exposed to osthole at concentrations of $0,50,100$ or $200 \mu \mathrm{M}$ for $48 \mathrm{~h}$, and the effect of osthole on the augmentation of apoptosis was investigated. The results of this analysis using flow cytometry demonstrated that osthole inhibited the growth of the U87 cells in a dose-dependent manner (Fig. 3). Treatment with 100 and $200 \mu \mathrm{M}$ osthole for $48 \mathrm{~h}$ significantly increased the apoptosis of U87 cells.

Inhibition of MMP-9 by osthole. To examine a potential association between the effect of osthole $(0,50,100$ of $200 \mu \mathrm{M})$ on the U87 cells and MMP-9, the protein expression levels of MMP-9 were determined using gelatin zymography assays. The data indicated that osthole inhibited the protein expression levels of MMP-9 in a dose-dependent manner (Fig. 4A). As shown in Fig. 4B, treatment with 100 and $200 \mu \mathrm{M}$ of osthole for $48 \mathrm{~h}$ significantly reduced the protein expression levels of MMP-9 in the U87 cells.

Osthole activates the expression of $m i R-16$. The present study aimed to determine the possible correlations between osthole $(0,50,100$ or $200 \mu \mathrm{M})$ and the expression levels of miR-16, which was assessed using RT-qPCR. The data indicated that osthole promoted the expression levels of miR-16 in a dose-dependent manner. As shown in Fig. 5, treatment with 100 and $200 \mu \mathrm{M}$ osthole for $48 \mathrm{~h}$ significantly promoted the expression of miR-16 in the U87 cells $(\mathrm{P}<0.05)$.

Overexpression of $\mathrm{miR}-16$ inhibits the protein expression of MMP-9. The protein expression levels of MMP-9 were examined following transfection of the U87 cells with miR-16. The results demonstrated that the protein expression levels of MMP-9 were reduced by overexpression of miR-16 in the U87 cells treated with $100 \mu \mathrm{M}$ osthole. As shown in Fig. 6A and B, the miR-16 overexpressing cells inhibited the protein expression of MMP-9.

Anti-miR-16 reverses the effect of osthole. To confirm the functional role of osthole and of miR-16 in mediating the effects on the viability of the U87 cells, the present study examined the activity of caspase- 3 and the protein expression levels of MMP-9 following transfection of the cells with anti-miR-16. The results indicated that transfection with the anti-miR-16 antibody efficiently penetrated into the U87 cells and significantly reduced the expression of miR-16 in the U87 cells (Fig. 7A). Following treatment with $100 \mu \mathrm{M}$ osthole for 


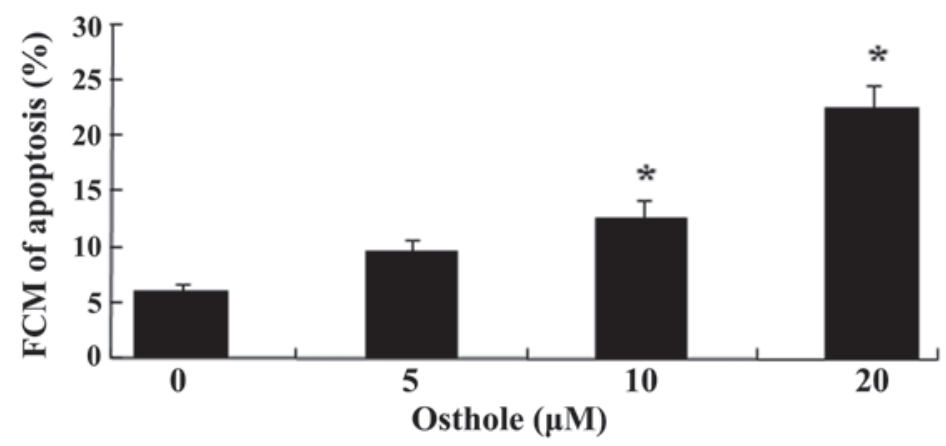

Figure 3. FCM analysis to detect levels of cellular apoptosis. Statistical analysis of the apoptosis of U87 cells. Data are presented as the mean \pm standard deviation ( ${ }^{*} \mathrm{P}<0.05$, compared with the $0 \mu \mathrm{M}$ osthole treatment group). $\mathrm{FCM}$, flow cytometric analysis.

A

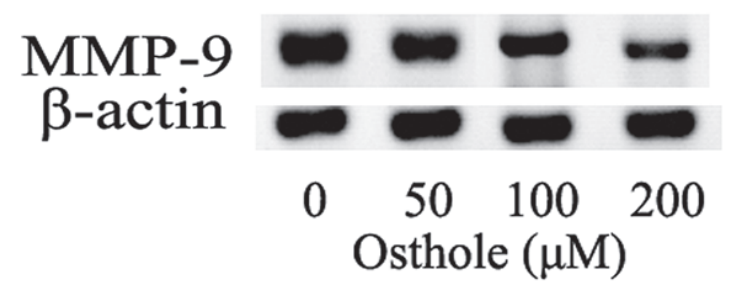

B

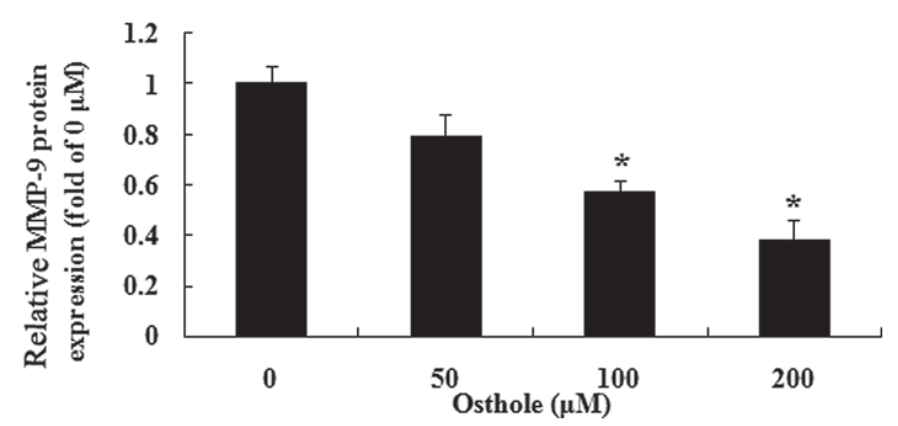

Figure 4. Osthole inhibits the expression of MMP-9. (A) Expression levels of MMP-9 were reduced in a dose-dependent manner in the U87 cells following treatment with $100 \mu \mathrm{M}$ osthole for $48 \mathrm{~h}$, determined using a gelatin zymography assay. (B) Protein bands were quantified and statistical analysis of the protein expression levels of MMP-9 was performed. Data are presented as the mean \pm standard deviation ( $\mathrm{P}<0.05$, compared with the $0 \mu \mathrm{M}$ osthole treatment group). MMP-9, matrix metalloproteinase-9.

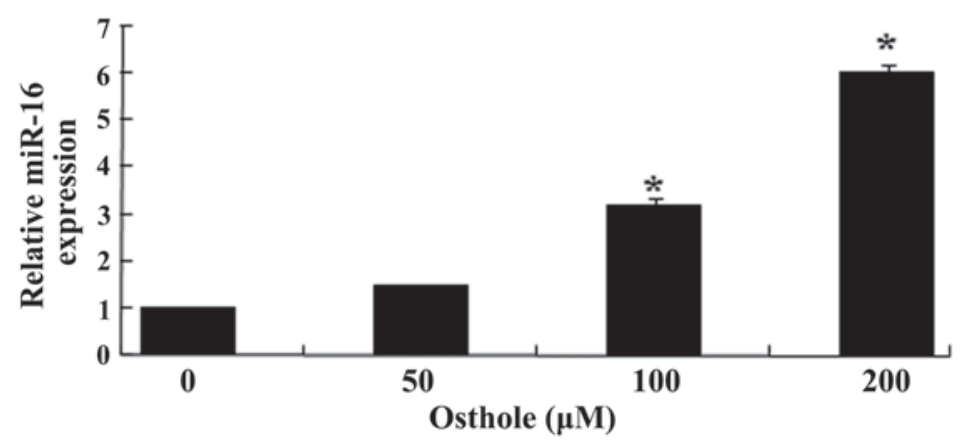

Figure 5. Osthole activates the expression of miR-16. Treatment with $100 \mu \mathrm{M}$ osthole for $48 \mathrm{~h}$ increased the expression levels of miR-16 in a dose-dependent manner Data are presented as the mean \pm standard deviation ( $\mathrm{P}<0.05$, compared with the $0 \mu \mathrm{M}$ osthole treatment group). miR, microRNA.

$48 \mathrm{~h}$, transfection with the anti-miR-16 antibody neutralized the effect of miR-16 on the U87 cells (Fig. 7B), inhibited the apoptotic effect on the U87 cells, indicated by downregulation in capsase-3 activity (Fig. 7C), and neutralized the inhibitory effect of osthole through downregulating the expression of MMP-9 (Fig. 7D).

\section{Discussion}

Glioma comprises $44.6 \%$ of tumors of the central nervous system and exhibit characteristics of a high recurrence rate and high mortality rate. With the development of molecular biology techniques, investigating glioma resistance mecha- nism has been achieved at the molecular gene level and, through increased investigation, a deeper understanding of the resistance mechanism of glioma has been demonstrated (15). Several studies have reported certain natural chemical and compound products, which exert anticancer effects on a wide variety of tumor types $(16,17)$. A previous study reported that osthole induces cell apoptosis and weakens cell migration in brain tumors (18). However, the detailed mechanisms underlying the anticancer effects of osthole on glioma remain to be fully elucidated. The present study demonstrated that osthole suppressed the proliferation and increased the activity of caspase- 3 in the U87 cells. These results were consistent with those of previous studies (19-21). For example, Ding et al (19) 
A

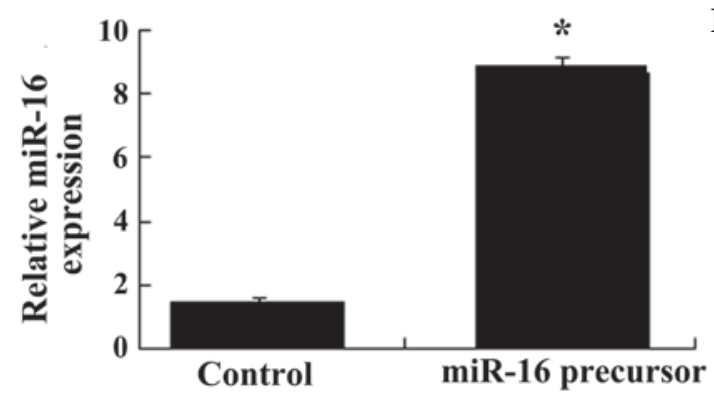

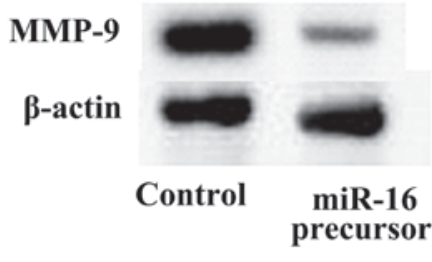

Figure 6. Overexpression of miR-16 and its effect on the expression levels of MMP-9. (A) Transfection with the miR-16 precursor significantly increased the expression levels of miR-16. (B) Transfection with the miR-16 precursor decreased the protein expression levels of MMP-9. Data are presented as the mean \pm standard deviation ("P<0.05, compared with the $0 \mu \mathrm{M}$ osthole treatment group). miR, microRNA; MMP-9, matrix metalloproteinase-9.

A

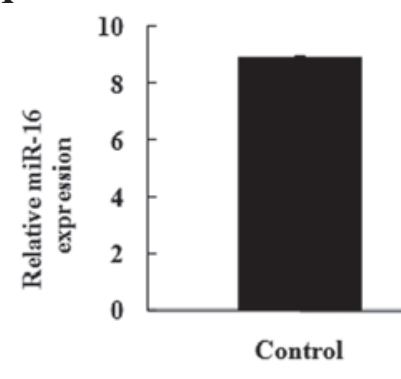

C

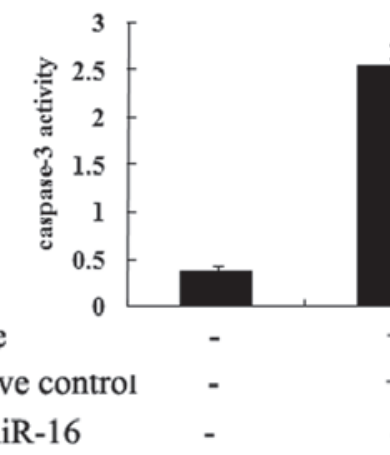

B

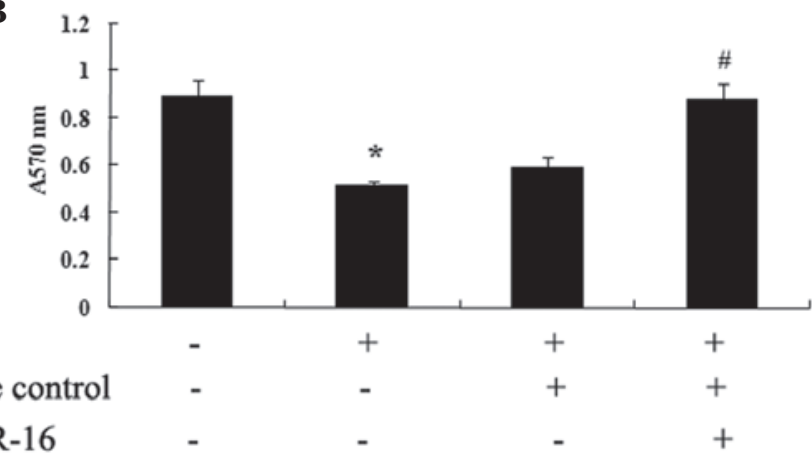

D

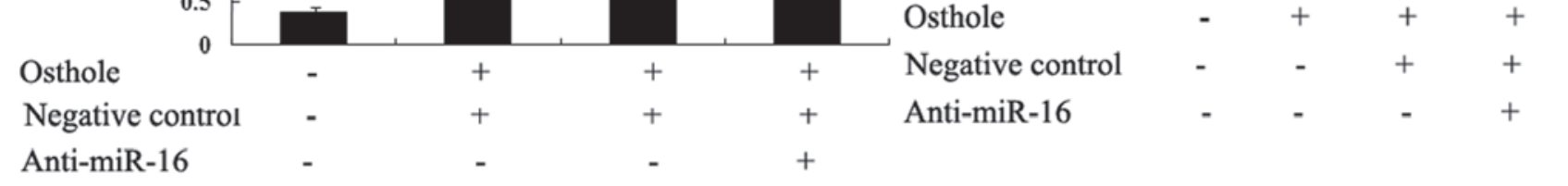

Figure 7. Anti-miR-16 reverses the effect of treatment with osthole. (A) Anti-miR-16 significantly reduced the expression levels of miR-16 in the U87 cells. Following treatment with $100 \mu \mathrm{M}$ osthole for $48 \mathrm{~h},(\mathrm{~B})$ anti-miR promoted cell proliferation, (C) anti-miR-16 markedly inhibited the apoptosis of the U87 cells and (D) anti-miR-16 significantly decreased the expression levels of MMP-9 ( ${ }^{*} \mathrm{P}<0.05$, compared with the $0 \mu \mathrm{M}$ osthole treatment group; ${ }^{\#} \mathrm{P}<0.01$, compared with osthole-treated group transfected with the negative control). miR, microRNA; MMP-9, matrix metalloproteinase-9.

demonstrated that osthole inhibits the proliferation, migration and invasion, and induces the apoptosis of glioma cells.

Osthole, isolated from the rumbrelliferae plant monomers of the ripe fruit, Cnidium monnieri, possesses anti-inflammatory properties, improves learning and memory, and inhibits thrombosis (22-24). In the present study, treatment of the U87 cells with osthole significantly increased the apoptosis of the cells. Osthole was previously observed to suppress cell proliferation and induce cellular apoptosis in NCI-H460 lung carcinoma cells, which corresponded with the present study (25).

The degradation of the extracellular matrix by MMPs via type II collagenase AB is associated with the invasive cell growth of glioma, with MMP-9 being the most closely associated with glioma and, to a certain extent, its expression can reflect the extent of glioma invasion within the body $(26,27)$.
The mRNA expression level of MMP-9 is closely associated with the degree of malignant glioma, and it has been reported that the intensity of MMP-9-positive staining is closely associated with the pathological levels of glioma (28). These reports indicate that MMP-9 can be used to determine the human glioma malignant phenotype (29). Using a nude mouse model to investigate the growth of glioma, it was determined that increased expression levels of MMP-9 are more marked, compared with the expression level of MMP-2, and indicates that MMP-9 is important in the growth of glioma (30). Consistently, the results of the present study demonstrated that treatment with osthole significantly reduced the protein expression levels of MMP-9. It was previously revealed that osthole suppresses the levels of MMP-2 and MMP-9 in A549 human lung cancer cells (31). In addition, osthole has been observed to inhibit NF- $\mathrm{kB}-\mathrm{MMP}-9$ in human lung adenocarcinoma (14). 
In the present study, RT-qPCR was used to identify possible correlations between osthole $(0,50,100$ or $200 \mu \mathrm{M})$ and the expression of miR-16. The data indicated that osthole promoted the expression of miR-16 in a dose-dependent manner. The expression levels of miR-16-1 were markedly reduced in the human glioma cell lines, which suggested that miR-16-1 is involved in the proliferative, migratory and invasive abilities of highly-invasive glioma cells (32). The present study demonstrated that upregulation of the expression of miR-16 reduced the protein expression levels of MMP-9 in the (U87 cells. In addition, the results revealed that downregulation of the expression of miR-16, via anti-miR-16 transfection, promoted the protein expression of MMP-9 in the U87 cells and reduced the effect of osthole on the proliferation and apoptosis of the U87 cells. In conclusion, the results of the present study suggested that osthole suppressed the proliferation and accelerated the apoptosis of U87 human glioma cells via upregulation of the expression of miR-16 and downregulation of the expression of MMP-9.

\section{Acknowledgements}

This study was supported by the Twelve-Five National Science and Technology Support Program (grant no. 2011BAI08B04).

\section{References}

1. Sun YC, Wang J, Guo CC, Sai K, Wang J, Chen FR, Yang QY, Chen YS, Wang J, To TS, et al: MiR-181b sensitizes glioma cells to teniposide by targeting MDM2. BMC Cancer 14: 611, 2014.

2. Cunha LC, Del Bel E, Pardo L, Stühmer W and Titze-DE-Almeida R: RNA interference with EAG1 enhances interferon gamma injury to glioma cells in vitro. Anticancer Res 33: 865-870, 2013.

3. Yang X, Lv S, Liu Y, Li D, Shi R, Tang Z, Fan J and Xu Z: The clinical utility of matrix metalloproteinase 9 in evaluating pathological grade and prognosis of glioma patients: a meta-analysis. Mol Neurobiol Aug 10, 2014.

4. Sun C, Wang Q, Zhou H, Yu S, Simard AR, Kang C, Li Y, Kong Y, An T, Wen Y, et al: Antisense MMP-9 RNA inhibits malignant glioma cell growth in vitro and in vivo. Neurosci Bull 29: 83-93, 2013.

5. Asuthkar S, Velpula KK, Chetty C, Gorantla B and Rao JS: Epigenetic regulation of miRNA-211 by MMP-9 governs glioma cell apoptosis, chemosensitivity and radiosensitivity. Oncotarget 3: 1439-1454, 2012.

6. Xia H, Qi Y, Ng SS, Chen X, Li D, Chen S, Ge R, Jiang S, Li G, Chen Y, et al: microRNA-146b inhibits glioma cell migration and invasion by targeting MMPs. Brain Res 1269: 158-165, 2009.

7. Cui Y, Bai Y, Wang XD, Liu B, Zhao Z and Wang LS: Differential expression of miRNA in rat myocardial tissues under psychological and physical stress. Exp Ther Med 7: 901-906, 2014.

8. Yan X, Liang H, Deng T, et al: The identification of novel targets of miR-16 and characterization of their biological functions in cancer cells. Mol Cancer 12: 92, 2013.

9. Zhu Y, Xia Y, Niu H and Chen Y: MiR-16 induced the suppression of cell apoptosis while promote proliferation in esophageal squamous cell carcinoma. Cell Physiol Biochem 33: 1340-1348, 2014.

10. Aqeilan RI, Calin GA and Croce CM: miR-15a and miR-16-1 in cancer: discovery, function and future perspectives. Cell Death Differ 17: 215-220, 2010.

11. Yang TQ, Lu XJ, Wu TF, Ding DD, Zhao ZH, Chen GL, Xie XS, Li B, Wei YX, Guo LC, et al: MicroRNA-16 inhibits glioma cell growth and invasion through suppression of BCL2 and the nuclear factor-kappaB1/MMP9 signaling pathway. Cancer Sci 105: 265-271, 2014

12. Wang XY, Dong WP, Bi SH, Pan ZG, Yu H, Wang XW, Ma T, Wang $\mathrm{J}$ and Zhang WD: Protective effects of osthole against myocardial ischemia/reperfusion injury in rats. Int J Mol Med 32: $365-372,2013$
13. Sun F, Xie ML, Zhu LJ, Xue J and Gu ZL: Inhibitory effect of osthole on alcohol-induced fatty liver in mice. Dig Liver Dis 41: 127-133, 2009.

14. Kao SJ, Su JL, Chen CK, Yu MC, Bai KJ, Chang JH, Bien MY, Yang SF and Chien MH: Osthole inhibits the invasive ability of human lung adenocarcinoma cells via suppression of NF-kappaB-mediated matrix metalloproteinase-9 expression. Toxicol Appl Pharmacol 261: 105-115, 2012.

15. Yang X, Lv S, Zhou X, Liu Y, Li D, Shi R, Kang H, Zhang J and $\mathrm{Xu} Z$ : The clinical implications of transforming growth factor beta in pathological grade and prognosis of glioma patients: A meta-analysis. Mol Neurobiol Aug 23, 2014.

16. Lu DY, Chang CS, Yeh WL, Tang CH, Cheung CW, Leung YM, Liu JF and Wong KL: The novel phloroglucinol derivative BFP induces apoptosis of glioma cancer through reactive oxygen species and endoplasmic reticulum stress pathways Phytomedicine 19: 1093-1100, 2012.

17. Tsai CF, Yeh WL, Huang SM, Tan TW and Lu DY: Wogonin induces reactive oxygen species production and cell apoptosis in human glioma cancer cells. Int J Mol Sci 13: 9877-9892, 2012.

18. Tsai CF, Yeh WL, Chen JH, Lin C, Huang SS and Lu DY: Osthole suppresses the migratory ability of human glioblastoma multiforme cells via inhibition of focal adhesion kinase-mediated matrix metalloproteinase-13 expression. Int J Mol Sci 15: 3889-3903, 2014.

19. Ding D, Wei S, Song Y, Li L, Du G, Zhan H and Cao Y: Osthole exhibits anti-cancer property in rat glioma cells through inhibiting PI3K/Akt and MAPK signaling pathways. Cell Physiol Biochem 32: 1751-1760, 2013

20. Wang L, Peng Y, Shi K, et al: Osthole inhibits proliferation of human breast cancer cells by inducing cell cycle arrest and apoptosis. J Biomed Res 29: 132-138, 2015.

21. Lin YC, Lin JC, Hung CM, et al: Osthole inhibits insulin-like growth factor-1-induced epithelial to mesenchymal transition via the inhibition of PI3K/Akt signaling pathway in human brain cancer cells. J Agric Food Chem 62: 5061-5071, 2014.

22. Liu J, Zhang W, Zhou L, Wang X and Lian Q: Anti-inflammatory effect and mechanism of osthole in rats. Zhong Yao Cai 28: 1002-1006, 2005

23. Zhang Q, Qin L, He W, Van Puyvelde L, Maes D, Adams A, Zheng $\mathrm{H}$ and De Kimpe $\mathrm{N}$ : Coumarins from Cnidium monnieri and their antiosteoporotic activity. Planta Med 73: 13-19, 2007.

24. Luszczki JJ, Andres-Mach M, Cisowski W, Mazol I, Glowniak K and Czuczwar SJ: Osthole suppresses seizures in the mouse maximal electroshock seizure model. Eur J Pharmacol 607: 107-109, 2009.

25. Xu XM, Zhang Y, Qu D, Liu HB, Gu X, Jiao GY and Zhao L: Combined anticancer activity of osthole and cisplatin in NCI-H460 lung cancer cells in vitro. Exp Ther Med 5: 707-710, 2013.

26. Singh MK, Bhattacharya D, Chaudhuri S, Acharya S, Kumar P, Santra P, Basu AK and Chaudhuri S: T11TS inhibits glioma angiogenesis by modulation of MMPs, TIMPs, with related integrin alphav and TGF- $\beta 1$ expressions. Tumour Biol 35: 2231-2246, 2014.

27. Kim MS, Kwak HJ, Lee JW, Kim HJ, Park MJ, Park JB, Choi KH, Yoo H, Shin SH, Shin WS, et al: 17-Allylamino-17-demethoxygeldanamycin down-regulates hyaluronic acid-induced glioma invasion by blocking matrix metalloproteinase-9 secretion. Mol Cancer Res 6: 1657-1665, 2008.

28. Huang HC, Huang CY, Lin-Shiau SY and Lin JK: Ursolic acid inhibits IL-1beta or TNF-alpha-induced C6 glioma invasion through suppressing the association ZIP/p62 with PKC-zeta and downregulating the MMP-9 expression. Mol Carcinog 48: 517-531, 2009.

29. Gondi CS, Lakka SS, Dinh DH, Olivero WC, Gujrati M and Rao JS: Downregulation of uPA, uPAR and MMP-9 using small, interfering, hairpin RNA (siRNA) inhibits glioma cell invasion, angiogenesis and tumor growth. Neuron Glia Biol 1: 165-176, 2004.

30. Pagliara V, Adornetto A, Mammi M, Masullo M, Sarnataro D, Pietropaolo C and Arcone R: Protease Nexin-1 affects the migration and invasion of C6 glioma cells through the regulation of urokinase Plasminogen Activator and Matrix Metalloproteinase-9/2. Biochim Biophys Acta 1843: 2631-2644, 2014.

31. Xu XM, Zhang Y, Qu D, Feng XW, Chen Y and Zhao L: Osthole suppresses migration and invasion of A549 human lung cancer cells through inhibition of matrix metalloproteinase- 2 and matrix metallopeptidase-9 in vitro. Mol Med Rep 6: 1018-1022, 2012.

32. Li X, Ling N, Bai Y, Dong W, Hui GZ, Liu D, Zhao J and Hu J: MiR-16-1 plays a role in reducing migration and invasion of glioma cells. Anat Rec (Hoboken) 296: 427-432, 2013. 